\author{
Michal Nowicki \\ Uniwersytet Wrocławski \\ e-mail: michal.nowicki@uwr.edu.pl
}

\title{
KRYZYS MIGRACYJNY JAKO KONSEKWENCJA BRAKU GLOBALNEGO KIEROWANIA W GOSPODARCE
}

\section{MIGRATION CRISIS AS A CONSEQUENCE OF A LACK OF GLOBAL ECONOMIC GOVERNANCE}

DOI: $10.15611 /$ pn.2018.523.24

Streszczenie: Tematem niniejszego opracowania jest kryzys migracyjny, jaki dotknął Unię Europejską w 2015 roku. Na artykuł składa się część statystyczna pokazująca skalę zjawiska, wskazanie problemu dysproporcji rozwojowych i ich krótka charakterystyka oraz opis aktualnych deficytów w global governance, które są przyczyną kryzysu. Jego celem jest ukazanie problemu kryzysu migracyjnego w szerszej perspektywie. Autor, odwołując się do koncepcji globalnego kierowania (global governance), wskazuje zaniedbania na szczeblu globalnym jako główną i pierwotną przyczynę tego problemu. Korzystając z dorobku ekonomii rozwoju, studiów nad Afryką, a także bazując na informacjach statystycznych i raportach organizacji międzynarodowych, ukazano czynniki, które w opinii autora finalnie doprowadziły do wielu zjawisk określanych jako kryzys migracyjny. W artykule wykorzystano metodę analizy i krytyki piśmiennictwa naukowego oraz metodę opisową.

Słowa kluczowe: migracje, global governance, kryzys migracyjny.

Summary: The article is about migration crisis which struck the European Union in 2015. The paper consists of three parts: in the first part, some statistic data are showed to enlight the scale of the described phenomenon, in the second part there is a description of the most important issues underdeveloped countries are dealing with and in the third part the deficiencies of global governance in this area are showed. The main goal of this article is to show a problem of the migration crisis in a wider perspective. The author, referring to the conception of global governance, points neglects on a global level as a primary and main reason for this problem. Basing on achievements of development economics, African studies, statistics and reports of international organisations, the factors, which lead to the crisis, are pointed out. In the article the analysis and critics of scientific literature and descriptive method were used.

Keywords: crisis, global governance, migration crisis. 


\section{Wstęp}

Mimo że na przełomie XX i XXI wieku oraz w pierwszej dekadzie nowego stulecia nie brakowało sygnałów wskazujących na konieczność potraktowania kwestii budowania global governance poważnie, dominowała perspektywa myślenia krótkofalowego - gaszenia pożarów, zamiast wyciągania wniosków i podejmowania działań długofalowych. Podobnie rzecz się ma z problemem migracji. Kryzys migracyjny dotyczył głównie Europy, ale również Stany Zjednoczone wciąż stanowią bardzo popularny kierunek ruchów ludności [Węgliński, s. 13-33]. Pewnym symbolicznym dowodem na bezsilność i nieadekwatność działań politycznych wobec tego zagadnienia są pomysły budowania murów: w przypadku USA na granicy z Meksykiem, w przypadku Unii Europejskiej - na zewnętrznych granicach tego ugrupowania. Wiele decyzji podejmowanych przez polityków obliczonych jest na zdobywanie uznania wyborców lub rozgrywanie sporów wewnętrznych, co powoduje utrwalanie się w społeczeństwie błędnego obrazu problemu. Śledząc informacje prasowe na temat kryzysu migracyjnego w polskich mediach, można dojść do wniosku, że jest to kwestia bądź okazania miłosierdzia osobom w potrzebie, bądź obrony przed zagrożeniem, jakim mają być przybysze obcy kulturowo. W publicznej debacie w Polsce nie wybrzmiało dobrze pytanie: Dlaczego setki tysięcy ludzi decydują się, często z narażeniem życia, a niemal zawsze zdrowia, na migrację do Europy? Jeśli z ogółu migrujących osób wyłączymy uchodźców z państw objętych wojną lub w których dochodzi do prześladowań politycznych, religijnych czy etnicznych, można zadać kolejne pytanie: Dlaczego tylu ludzi decyduje się na migrację, która wiąże się z bardzo dużym prawdopodobieństwem utraty życia lub zdrowia (szczególnie tyczy się to osób próbujących przepłynąć Morze Śródziemne z Afryki do Europy, ale także migrantów zmierzających do Stanów Zjednoczonych drogą morską)? Czy naprawdę tysiące ludzi podejmują ryzyko utraty życia tylko po to, by żyć na zasiłkach socjalnych w bogatych państwach Europy Zachodniej i Północnej?

Celem niniejszego artykułu jest umiejscowienie problemu kryzysu migracyjnego w szerszej, globalnej perspektywie. Autor stawia hipotezę, że pierwotną przyczyną zjawisk, które doprowadziły do wybuchu kryzysu migracyjnego, były wieloletnie zaniedbania w budowaniu globalnego ładu, szczególnie w obszarze ekonomicznym. W artykule zarysowana zostaje problematyka państw słabo rozwiniętych gospodarczo, będących miejscami, z których migranci wyruszają, a także wskazane są deficyty w global governance na przestrzeni lat i obecnie. Autor wykorzystuje metodę analizy i krytyki piśmiennictwa naukowego oraz metodę opisową. W pierwszej części artykułu znajdują się także dane statystyczne obrazujące kulminacyjny moment kryzysu migracyjnego. Istotne dla powstania artykułu były także informacje prasowe i obserwacje autora w zakresie postaw polityków i społeczeństwa wobec opisywanego zjawiska. 


\section{Kryzys migracyjny - informacje wstępne ${ }^{1}$}

Migracje do Europy, jak pisze J. Szymańska, nie są zjawiskiem nowym. Jednak ostatnimi czasy odnotowujemy nasilenie tego procesu. Pierwszą falę ruchów ludności na terytorium Unii Europejskiej, zwiastującą kryzys migracyjny, można było zaobserwować w następstwie tzw. arabskiej wiosny w 2011 roku. Jednak jego kulminacja przypada na rok 2015 [Szymańska 2017, s. 159-160]. Jak zauważa K. Jędrzejczyk-Kuliniak, opisywane zjawisko to w zasadzie kilka nakładających się na siebie kryzysów. Autorka wymienia następujące:

- Kryzys migracyjny w ujęciu demograficznym.

- Kryzys uchodźczy związany z ruchem osób z Afryki Północnej i Bliskiego Wschodu.

- Kryzys polityki azylowej Unii Europejskiej, o charakterze prawnoinstytucjonalnym [Jędrzejczyk-Kuliniak 2017, s. 100-101].

Tabela 1. Liczba wnioskujących o azyl w krajach Unii Europejskiej pod względem kraju pochodzenia

\begin{tabular}{|l|c|}
\hline \multicolumn{1}{|c|}{ Kraj pochodzenia } & Liczba wnioskujących o azyl \\
\hline Syria & 362775 \\
\hline Afganistan & 178230 \\
\hline Irak & 121535 \\
\hline Kosowo & 66885 \\
\hline Albania & 65935 \\
\hline Pakistan & 46400 \\
\hline Erytrea & 33095 \\
\hline Nigeria & 29915 \\
\hline Iran & 25360 \\
\hline Inne & 325510 \\
\hline Ogółem & 1255640 \\
\hline
\end{tabular}

Źródło: [House of Commons 2016, s. 13].

Jak pokazuje tab. 1, w 2015 roku 1225640 osób zgłosiło wniosek o azyl w państwach Unii Europejskiej. Wśród nich najliczniej reprezentowaną nacją byli Syryjczycy (362 775 wniosków), na drugim miejscu Afgańczycy (178 230 wniosków), a na trzecim Irakijczycy (121 535 wniosków). Wnioski azylowe obywateli tych trzech krajów Bliskiego Wschodu, które w XXI wieku dotknięte były lub są konfliktami zbrojnymi, stanowiły zatem ponad połowę łącznej liczby zgłoszeń. Dane Eurostatu, na podstawie których powstała tab. 1, wskazują, że najczęściej wnioski o azyl

1 Teorie migracji opisane są m.in. w [Janicki 2015, s. 81-86; Zimmermann (red.) 1992]. Szerzej o przyczynach migracji zewnętrznej w XXI wieku piszą m.in. [Castles, Miller 2011; Palat 2011; Mohapatra, Ratha, Scheja 2011; Węgliński 2012; Małachowski 2010, s. 13-61; Krawczyńska-Butrym 2009; Cieślińska 2012]. Ze względu na ograniczoną objętość artykułu autor odsyła wszystkich zainteresowanych tymi zagadnieniami do powyższych pozycji. 
zgłaszano w Niemczech (35\% ogólnej liczby), na Węgrzech (14\%), w Szwecji (12\%), w Austrii (7\%), we Włoszech (7\%) i Francji (6\%). Krajami, które zanotowały w 2015 roku największy wzrost, rok do roku, liczby wniosków azylowych, były: Finlandia (+822\%), Węgry (+323\%), Austria (+233\%), Belgia (+178\%), Hiszpania (+167\%) i Niemcy $(+155 \%)$. W porównaniu z populacją kraju największa liczba wniosków wpłynęła na Węgrzech (17 699 wniosków na milion mieszkańców), następnie w Szwecji, Austrii, Finlandii i w Niemczech. Natomiast najniższą wartość wskaźnik ten miał w Chorwacji (34 wnioski na milion mieszkańców), Słowacji, Rumunii, Portugalii i na Litwie [Eurostat].

Podane powyżej liczby są rozbiciem statystycznym największego strumienia migracji do Europy od zakończenia II wojny światowej. Jednak jak podaje UNHCR, na Bliskim Wschodzie i w krajach Maghrebu ogólna liczba migrantów (uchodźców i innych osób) przekraczała wtedy 16 milionów. Tylko w państwach ościennych Syrii w tym czasie znajdowało się ok. 4 milionów syryjskich uchodźców [Instytut Obywatelski 2015, s. 2-3]. Pokazuje to realną wielkość problemu.

Fakt, że blisko 29\% wnioskujących o azyl w państwach UE w 2015 roku pochodziło z Syrii nie jest oczywiście przypadkiem, podobnie jak wysoka reprezentacja Afganistanu i Iraku. W ostatnich latach liczba uchodźców wśród osób migrujących znacznie wzrosła, osiągając rekordowe wielkości [Crawley 2016, s. 14-15]. Jest to efekt konfliktów, które w XXI wieku dotknęły obszar Bliskiego Wschodu (wojna w Afganistanie, Iraku, Syrii), a także ,arabskiej wiosny ludów” oraz utrzymującej się niestabilności politycznej w wielu krajach Afryki. Jednak w poszukiwaniu genezy kryzysu migracyjnego można i należy spojrzeć na szerszy obraz, analizując to zjawisko w kontekście skutków globalizacji, szczególnie w jej ekonomicznej odsłonie.

\section{Dysproporcje w poziomie rozwoju gospodarczego - nierozwiązany globalny problem}

Wśród głównych problemów o wymiarze globalnym istnieje jeden „metaproblem”, który ma bardzo bezpośrednie, doraźne skutki. Tym „metaproblemem” są dysproporcje w rozwoju gospodarczym $\mathrm{i}$ istnienie licznych obszarów bardzo słabo rozwiniętych ${ }^{2}$. Jest to „metaproblem”, gdyż wiąże się z wieloma węższymi problemami, m.in.: głodem, wysoką śmiertelnością noworodków, ekstensywnym wykorzystywaniem surowców naturalnych, epidemiami chorób (m.in. AIDS i malarii) [Garbicz 2012, s. 132]. Problem niskiego poziomu rozwoju gospodarczego często idzie także w parze z niestabilnością polityczną, terroryzmem, łamaniem praw człowieka. Widać to na przykładach państw, takich jak Afganistan, Kambodża, Mjanmar, Rwanda, Czad czy Kongo.

2 Według raportu UNCTAD The Least Developed Countries Report 2017 obecnie w kategorii państw najsłabiej rozwiniętych gospodarczo znajduje się 46 krajów [UNCTAD 2017]. 
Przyczyny problemów państw słabo rozwiniętych gospodarczo są bardzo dobrze opisane $\mathrm{w}$ literaturze. Najbardziej znaną teorią z tego zakresu jest opracowana przez G. Myrdala i R. Nurske idea „zaklętych kręgów ubóstwa” [Noga, Stawicka (red.) 2009, s. 57]. O przyczynach tych problemów piszą m.in. P. Krugrman i M. Obsfeld, J.E. Stigliz [Krugrman, Obsfeld 2007, s. 467-472; Stigliz 2007], wymieniają je B. Fiedor i K. Kociszewski [2010, s. 183-184]. K. Czernichowski, D. Kopiński i A. Polus wskazują na „klątwę surowcową” jako przyczynę zacofania niektórych z tych państw [Czernichowski, Kopiński, Polus 2012], inni, jak B. Davidson, na skutki epoki kolonializmu [Davidson 2011, s. 211-212, 234]³.

Temat efektywności pomocy rozwojowej jest bardzo często poruszany w literaturze ${ }^{4}$. Państwa słabo rozwinięte gospodarczo są objęte licznymi programami pomocowymi (m.in. GSP w ramach WTO, AID for trade, Milenijne Cele Rozwoju i ich następczyni - Agenda Zrównoważonego Rozwoju 2030). Jednak mimo wymiernych sukcesów, liczonych w redukcji liczby osób żyjących za minimum egzystencjalne, niemających dostępu do czystej wody, czy spadku śmiertelności niemowląt, nie można mieć wątpliwości, że problemy, z jakimi borykają się te państwa, są dalekie od rozwiązania.

\section{Niedostatki w globalnym kierowaniu gospodarką}

Koncepcja global governance powstała na początku lat 90. XX wieku jako odpowiedź na zmiany wywołane procesem globalizacji. Pierwotnie w centrum jej zainteresowania znajdowały się kwestie budowania ładu globalnego w ujęciu politycznym, z biegiem czasu silne znaczenie zyskały takie nurty, jak global economic governance i global environmental governance. Realizacja idei globalnego kierowania miała zapewnić globalne mechanizmy pozwalające rozwiązywać najważniejsze problemy ery globalizacji. W miejsce coraz bardziej dysfunkcyjnych państw, skostniałego systemu instytucji międzynarodowych zdominowanych przez Stany Zjednoczone i Unię Europejską miał powstać nowy, zdemokratyzowany ład uwzględniający specyfikę zglobalizowanego świata. W obszarze gospodarki miało się to przejawiać stworzeniem globalnej architektury finansowej, reformą światowego systemu handlu, promowaniem zrównoważonego rozwoju i skuteczną pomocą rozwojową dla Afryki oraz innych obszarów dotkniętych asymetrią skutków globalizacji gospodarki [Nowicki 2013]. Jednak wspomniana powyżej niska efektywność pomocy rozwojowej i widoczny regres w budowania global governance spowodował, że globalne problemy pozostają nierozwiązane.

3 Inne pozycje poruszające to zagadnienie to m.in. [Solarz (red.) 2011; Sylos Labini 2001; Deszczyński 2010; Kopiński, Polus (red.) 2010; Jarecka-Stępień, Kościółek (red.) 2012].

4 Poświęcone są mu zarówno publikacje w periodykach naukowych [Vathis 2013; Mercieca 2010; Sachs, Ayittey 2009], jak i raporty instytucji międzynarodowych, takich jak Bank Światowy [Goldin, Rogers, Stern 2002], MFW [Minoiu, Reddy 2009], WTO i OECD [OECD, WTO 2013]. 
Świadomość w społeczeństwach państw europejskich odnośnie do zagadnienia pomocy prorozwojowej dla państw rozwijających się zdaje się ograniczać do tego, że ONZ, Unia Europejska i inne organizacje (rządowe i pozarządowe) prowadzą różne działania, które finansują m.in. ich rządy. Widać to po powszechnym w Polsce „rozwiązaniu” kryzysu migracyjnego, które zawiera się w twierdzeniu „pomóżmy im na miejscu”, co oznacza de facto: „dajmy im jeszcze trochę pieniędzy”. Co ciekawe, wydaje się to być także credo polityki skierowanej do LDC i innych słabo rozwiniętych krajów. Przez dekady nie odważono się podjąć przełomowych decyzji w sprawie pomocy dla najbiedniejszych regionów świata, gdyż decyzje te są politycznie niepopularne. Świadomie godzono się na ład, w którym korzyści z globalizacji odnosiły głównie państwa najbogatsze, wygrywające konkurencję w obszarach, które uległy silnej liberalizacji. De facto to ład utrwalający wiele z podziałów, które powstały w epoce kolonializmu i rewolucji przemysłowej. Dominacja Stanów Zjednoczonych i Unii Europejskiej na forum głównych organizacji międzynarodowych zapewniała tym państwom ochronę w najbardziej wrażliwych aspektach, np. w sektorze rolnictwa czy przemyśle tekstylnym. Niedemokratyczny charakter obecnego ładu stanowi więc swoisty gwarant ochrony ich interesów i zapewnia relatywny spokój politycznym decydentom w państwach wysoko rozwiniętych. Przez całe dekady nie uwzględniano punktu widzenia małych i słabych gospodarczo państw. Wyznaczano sztuczne granice państw, które do dziś skutkują konfliktami w Afryce [Meredith 2011]. Forsowano odgórnie narzucone modele zarządzania gospodarką, a często także próbowano implementować system demokratyczny, nie zapewniając żadnych trwałych fundamentów pod jego budowę 5 . W efekcie od zakończenia II wojny światowej i po uzyskaniu niepodległości przez państwa będące koloniami narastała rozbieżność w poziomie życia między państwami, które w światowym ładzie były rozgrywającymi, a państwami, które były rozgrywane. Uwaga świata zachodniego skupiona była na odbudowie gospodarczej po II wojnie światowej i rozwijaniu procesu globalizacji i na tym polu poczyniono znaczne sukcesy. Jednak brakowało cały czas pomysłu na „Trzeci Świat”. Ten traktowany instrumentalnie stał się w XXI wieku kolebką terroryzmu, areną wojen między państwami i wewnątrz państw, obszarem dotkniętym głodem, analfabetyzmem i biedą [Kłosiński (red.) 2012; Leszczyński 2012]. Jednocześnie obszar ten nie został zupełnie wykluczony przez proces globalizacji. J.E. Stigliz zauważył, że wraz z rozwojem globalizacji rosła nie tylko dysproporcja między bogatymi a biednymi, ale także świadomość nierówności między różnymi regionami świata [Stigliz 2007, s. 26-32].

5 Stanisław Lem w rozmowie z Grzegorzem Miecugowem użył metafory, że świat zachodni traktuje demokrację jak paprotkę, którą można wziąć i zasadzić w dowolnym miejscu. 


\section{Kryzys migracyjny a globalne kierowanie}

Szukając genezy, praprzyczyny kryzysu migracyjnego, zdaniem autora, należy sięgnąć do omawianych powyżej zaniedbań na szczeblu międzynarodowym. Oczywiście nie sposób nie zgodzić się z podawanymi w literaturze wytłumaczeniami tego zjawiska [Dahl, Dudzik 2017; PWC 2017; Upadhyay 2016; Jommy 2016]. Prawdą jest, że w strumieniach migrantów zmierzających do Europy byli i są uciekinierzy z Syrii i innych obszarów, na których prowadzone są działania wojenne. Są wśród nich osoby prześladowane ze względu na wiarę, przynależność etniczną i z przyczyn politycznych. Bez wątpienia część z nich to osoby poszukujące lepszych warunków do życia ${ }^{6}$. Jednak te przyczyny, w opinii autora, są wtórne wobec deficytu globalnego kierowania. De facto jest to problem braku zarówno ekonomicznego, jak i politycznego global governance. Obie sfery mocno się na siebie nakładają. Stany Zjednoczone od czasów wojny secesyjnej nie były areną działań wojennych. Idea integracji europejskiej przyczyniła się do tego, że od zakończenia II wojny światowej na obszarze objętym integracją nie doszło do żadnego konfliktu zbrojnego. Tymczasem na terenach byłych kolonii państw europejskich ciągle dochodzi do wojen, przewrotów politycznych itd. Wiele z nich było lub jest aktualnie przedmiotem rozgrywek między mocarstwami (Afganistan w czasie ,zimnej wojny”, współczesna Syria). Po zakończeniu II wojny światowej liczne państwa odzyskiwały formalną niepodległość. Jednak niewielu z nich udało się uzyskać polityczną stabilność i zbudować gospodarkę na tyle wydajną, by zapewnić możliwość doganiania byłych metropolii.

Gdy połączyć tę informację z faktem, że w wieku XX obserwowaliśmy najbardziej dynamiczny przyrost liczby ludności w historii, a najszybciej rośnie liczba ludności w Afryce i Azji, fakt masowych migracji z tych dwóch kontynentów do Europy, która od dłuższego czasu boryka się z problemami demograficznymi [Czerny 2005, s. 53-55], nie może dziwić, nawet z pominięciem czynników politycznych (wojny, prześladowania polityczne). Przyjmując taką optykę, można zatem uznać, że migracje ekonomiczne stanowią swoistą odpowiedź na nieskuteczną politykę międzynarodową skierowaną do państw słabo rozwiniętych. Bardzo trafnie ujęła to I. Jakimowicz-Ostrowska, pisząc: „Migranci XXI wieku to zatem coraz bardziej świadomi, z własnej woli czy przymuszeni okolicznościami, podróżnicy, których droga wiedzie szlakiem regulacji i zasad ułatwiających realizację ich pragnienia, jakim jest zmiana miejsca zamieszkania. Dzisiejsza Europa stworzyła swoim mieszkańcom dogodne warunki do przemieszczania się i umożliwiła swobodny wybór miejsca zmieszkania i osiedlenia się. $Z$ drugiej zaś strony otoczona jest przez regiony, w których dynamizm zjawisk oraz niestabilność polityczna zmusza ich ludność do poszukiwania nowych, bardziej bezpiecznych miejsc zamieszkania. Powoduje

${ }^{6} \mathrm{Z}$ punktu widzenia idei artykułu rzeczą drugorzędną jest to, czy są to osoby chcące żyć dzięki zasiłkom socjalnym, czy gotowe do podjęcia pracy. 
to, że kraje starego kontynentu, które do tej pory uchodziły za państwa emigrantów, np. Hiszpania, Włochy czy Grecja, stały się terenami zmagającymi się z coraz większym natężeniem napływających kolejnych fal imigrantów z obszarów pozaeuropejskich. Przyznanie się do problemów z imigracją zewnętrzną jednocześnie wiąże się z koniecznością zauważenia, że świat wokół Unii boryka się z takimi problemami, jak ubóstwo, analfabetyzm czy brak poczucia bezpieczeństwa, o których mieszkańcy Europy już dawno zdążyli zapomnieć lub uznać za niedotyczące ich" [Jakimowicz-Ostrowska 2011, s. 358]. Zdaje się, że nie tylko Unia Europejska, ale szerzej - bogata Północ, nie chce zauważyć realnego źródła tych problemów. Wśród opinii najważniejszych polityków europejskich i amerykańskich nie słychać przyznania się do winy. W obecnej sytuacji politycznej trudno się go spodziewać po prezydencie Federacji Rosyjskiej - Władimirze Putinie, jak również po jego amerykańskim odpowiedniku - Donaldzie Trumpie. A to te dwa kraje (przyjmując, że Rosja jest kontynuatorką ZSRR) w największym stopniu odpowiadają za obecny stan rzeczy. Jednak również państwa Unii Europejskiej i sama Unia mają udział w tej winie. W ujęciu historycznym - jako byłe mocarstwa kolonialne (m.in. Francja, Wielka Brytania, Holandia, Włochy, Portugalia), ale także współcześnie. W sferze zarówno politycznej (zaangażowanie krajów UE w konflikty zbrojne m.in. w Afganistanie, Iraku, Libii), jak i ekonomicznej (m.in. ochrona rynku wewnętrznego w obszarze rolnictwa) organizacja ta i jej członkowie przyczynili się do pogłębiania problemów regionów o najniższym poziomie rozwoju gospodarczego.

Rola global governance w tym obszarze jest dwojaka. Z jednej strony, to stworzenie warunków do dynamicznego rozwoju LDC i innych państw słabo rozwiniętych. Z drugiej strony - stworzenie systemu międzynarodowego, który spowodowałby, że migracje międzynarodowe, które są immanentną cechą globalizacji, przebiegałyby w sposób bardziej uporządkowany. W drugim działaniu celem jest zarówno ograniczenie (wyeliminowanie) procederów przestępczych (działalność wyspecjalizowanych grup, które organizują nielegalne przekroczenie granic), jak i sprawne włączenie migrantów do życia społecznego i gospodarczego państw goszczących ${ }^{7}$. Obecnie jednak proces przyjmowania imigrantów i uchodźców na terenie Unii Europejskiej przebiega chaotycznie, proponowane rozwiązania są nieskuteczne i nie zyskują powszechnej akceptacji, sam zaś proces migracji stanowi źródło dochodu dla zorganizowanych grup przestępczych i często wiąże się z narażeniem życia i zdrowia. Mimo że uwaga opinii publicznej skupiona jest głównie na działaniach wewnątrz Unii Europejskiej i na strumieniach migrantów zmierzających na jej terytorium, elementem global economic governance w tym obszarze jest również zapewnienie warunków bytowych uchodźcom, którzy znaleźli się w państwach sąsiadujących z ich krajem przymusowej migracji. To dziś casus

7 Wiele wartościowych uwag na temat budowania globalnego kierowania procesem migracji zawartych jest w raporcie „Towards Global Governance of International Migration: 15 years of intergovernmental recommendations and conclusions. A State of the Art Review" stworzonym przez W. Massa i K. Kosera na zlecenie The Hague Process on Refugees and Migration (THP) [THP 2010]. Inne pozycje poświęcone temu zagadnieniu to [Biermann, Boas 2010; Newland 2005; Papademetrieu 2011]. 
m.in. Turcji i Libanu. Tutaj także brakuje globalnej koordynacji, co rodzi kolejne problemy. Nawet jeśli obserwujemy czasowe spowolnienie dynamiki migracji, bez global governance problem ten niechybnie ponownie się nasili.

\section{Zakończenie}

Kryzys migracyjny, który dotknął Unię Europejską w ostatnich latach, uwypuklił wiele problemów. Pokazał konflikty i brak solidarności wewnątrz UE, zweryfikował skuteczność unijnej polityki migracyjnej, stanowił także poważne wyzwanie dla bezpieczeństwa wewnętrznego całej wspólnoty. $Z$ tego powodu uwaga mediów, polityków i wielu badaczy skupiła się na perspektywie krótkookresowej, na doraźnych przyczynach i środkach zaradczych, które należy podjąć. Jednak ów kryzys ma także „drugie dno". Stanowi on bardzo bolesne przypomnienie o tym, że trwający od zakończenia II wojny proces budowania nowego, globalnego ładu przyniósł bardzo asymetryczne efekty. Doprowadziło to do sytuacji, w której część państw żyje na bardzo wysokim poziomie, bez konieczności martwienia się o zaspokajanie potrzeb z dołu piramidy Maslowa, podczas gdy w innych krajach nawet potrzeby fizjologiczne nie zawsze są zaspokajane. Stanowi to, niezależnie od czynników, takich jak wojny czy prześladowania, bardzo silny impuls do migracji z państw biednych do bogatych. To jedyne racjonalne wytłumaczenie tego, że wielu z tych ludzi ryzykuje życie, by dotrzeć do brzegów Europy. Tak długo, jak nie uda się rozwiązać problemów LDC i innych zacofanych gospodarczo regionów i jak długo kooperacja nie zastąpi rywalizacji, nie uda się zlikwidować przyczyn, które doprowadziły do kryzysu migracyjnego. W 2015 roku te problemy zapukały do drzwi Europy. Ale nawet kiedy tego pukania nie słychać, to nie znaczy, że one nie istnieją.

\section{Literatura}

Biermann F., Boas I., 2010, Preparing for a warmer world: towards a global governance system to protect climate refugees, Global Environmental Politics, volume 10, number 1.

Castles S., Miller M.J., 2011, Migracje we współczesnym świecie, Wydawnictwo Naukowe PWN, Warszawa.

Cieślińska B., 2012, Emigracje bliskie i dalekie. Studium współczesnych emigracji zarobkowych na przykładzie województwa podlaskiego, Wydawnictwo Uniwersytetu w Białymstoku, Białystok.

Crawley H., 2016, Managing the unmanageable? Understanding Europe's response to the migration "crisis", Human Geography 9(2).

Czernichowski K., Kopiński D., Polus A., 2012, Klątwa surowcowa w Afryce? Przypadek Zambii i Botswany, CeDeWu.pl, Warszawa.

Czerny M., 2005, Globalizacja a rozwój. Wybrane zagadnienia geografii społeczno-gospodarczej świata, PWN, Warszawa.

Dahl M., Dudzik A., 2017, Państwa Unii Europejskiej wobec kryzysu imigracyjnego, UniaEuropejska.pl, nr 3(244). 
Davidson B., 2011, Spoteczna i polityczna historia Afryki w XX wieku, PWN, Warszawa.

Deszczyński P., 2010, Kraje rozwijajace się w stosunkach międzynarodowych, Wydawnictwo Wyższej Szkoły Bankowej, Poznań.

Eurostat, http://ec.europa.eu/eurostat/documents/2995521/7203832/3-04032016-AP-EN.pdf/790eba01-381c-4163-bcd2-a54959b99ed6 (dostęp 18.03.2018).

Fiedor B., Kociszewski K. (red.), 2010, Ekonomia rozwoju, UE Wrocław, Wrocław.

Garbicz M., 2012, Problemy rozwoju i zacofania ekonomicznego. Dlaczego jedne kraje sa biedne, podczas gdy inne sa bogate?, Oficyna Wolters Kulwer business, Warszawa.

Goldin I., Rogers H., Stern N., The Role and Effectiveness of Development Assistance, Lessons from World Bank Experience, https://pdfs.semanticscholar.org/1ac4/304728499b2378b861435320a9068424b834.pdf (dostęp 18.03.2018).

House of Commons: Home Affairs Committee, 2016, Migration Crisis. Seventh Report of Session 2016-17.

Instytut Obywatelski, Polska wobec kryzysu migracyjnego w Europie, http://www.instytutobywatelski. p1/25576/publikacje/analizy/spoleczenstwo-analizy/polska-wobec-kryzysu-migracyjnego-w-europie (dostęp 17.03.2018).

Jakimowicz-Ostrowska I., Imigracje do Europy wyzwaniem XXI wieku - przypadek Grecji, [w:] Rocznik Bezpieczeństwa Międzynarodowego 2010/2011, Wrocław 2011.

Janicki W., 2015, Migracje kompensacyjne jako czynnik wzrostu obszarów peryferyjnych. Rola ukrytego kapitału ludzkiego, Wydawnictwo Uniwersytetu Marii Curie-Skłodowskiej, Lublin.

Jarecka-Stępień K., Kościółek J. (red.), 2012, Problemy współczesnej Afryki. Szanse i wyzwania na przyszłość, Księgarnia Akademicka, Kraków.

Jędrzejczyk-Kuliniak K., 2017, Ten inny, obcy, imigrant. Europejska przestrzeń bezpieczeństwa a kryzys migracyjny, [w:] J.B. Banach-Gutierrez, M. Jabłoński (red.), Aktualne problemy ochrony wolności i praw mniejszości w Polsce i na świecie, E-Wydawnictwo. Prawnicza i Ekonomiczna Biblioteka Cyfrowa. Wydział Prawa, Administracji i Ekonomii Uniwersytetu Wrocławskiego, Wrocław.

Jommy F., Linka A. (red.), Polska i Europa wobec kryzysu imigracyjnego. W poszukiwaniu złotego środka http://www.mniejemocji.pl/pliki/Publikacja_www.pdf (dostęp 18.03.2018).

Kłosiński K.A., (red.), Afryka o godność życia, KUL, Lublin 2012.

Kopiński D., Polus A. (red.), 2010, Zgubne transakcje. Surowce mineralne a rozwój państw afrykańskich, Difin, Warszawa.

Krawczyńska-Butrym Z., 2009, Migracje. Wybrane zagadnienia., Wydawnictwo Uniwersytetu Marii Curie-Skłodowskiej, Lublin.

Krugman P.R., Obsfeld M., 2007, Ekonomia międzynarodowa. Teoria i polityka, t. 1, PWN, Warszawa.

Leszczyński A., 2012, Dziękujemy za palenie. Dlaczego Afryka nie może sobie poradzić z przemoca, głodem, wyzyskiem i AIDS, PAH, Warszawa.

Małachowski W., 2010, Migracje we wspótczesnym świecie. Implikacje dla Polski, Oficyna Wydawnicza Szkoła Główna Handlowa w Warszawie, Warszawa.

Mercieca P., 2010, Aid and economic growth in developing countires: a literature review, Bank of Valetta Review, no. 41.

Meredith M., 2011, Historia wspótczesnej Afryki. Pót wieku niepodległości, Dialog, Warszawa.

Minoiu C., Reddy S.G., Development Aid and Economic Growth: A Positive Long-Run Relation, https://www.imf.org/external/pubs/ft/wp/2009/wp09118.pdf (dostęp 18.03.2018).

Newland K., 2005, The governance of international migration: mechanisms, processes and institutions, Migration Policy Institute.

Noga M., Stawicka M.K. (red.), 2009, Kraje rozwijajace się Azji Poludniowo-Wschodniej i ich wpływ na rozwój gospodarczy Polski, CeDeWu.pl, Warszawa.

Nowicki M., 2013, Global governance jako kierunek rozwoju ładu międzynarodowego w erze globalizacji, Nauki Społeczne. Social Sciences, $\mathrm{nr}$ 2(8). 
Palat M., 2011, Economic causes and consequences of international migration of labor. Wirtschaftliche Auswirkungen der internationalen Arbeitsmigration, Estonian Discussions on Economic Policy, 19(2).

Papademetrieu D.G., 2011, The Governance of International Migration. Defining Potential for Reform in the Next Decade, Migration Policy Institute.

Ratha D., Mohapatra S., Scheja E., 2011, Impact of migration on economic and social development: a review of evidence and emerging issues (English), Policy Research working paper, no. WPS 5558. Washington, DC: World Bank. http://documents.worldbank.org/curated/en/617151468332982240/ Impact-of-migration-on-economic-and-social-development-a-review-of-evidence-and-emerging-issues.

Sachs J., Ayittey G.B.N., Can Foreign Aid Reduce Poverty?, http://www.earth.columbia.edu/sitefiles/ file/about/director/2009/Controversies\%20in\%20Globalization\%20Chapter\%203_Can\%20foreign\%20aid\%20reduce\%20poverty.pdf (dostęp 18.03.2018).

Solarz M.W. (red.), 2011, Kraje rozwijajace się na początku XXI wieku. Wybrane problemy, Wydawnictwo Uniwersytetu Warszawskiego, Warszawa.

Stiglitz J.E., 2007, Wizja sprawiedliwej globalizacji. Propozycje usprawnień, PWN, Warszawa.

Sylos Labini P., 2001, Underdevelopment. A Strategy for Reform, Cambridge University Press.

Szymańska J., 2017, Strategia Unii Europejskiej wobec kryzysu migracyjnego: priorytety, bariery, efekty, Studia BAS nr 3(51), Warszawa.

The Hague Process, Towards global governance of migration. 15 years of intergovernmental recommendations and conclusions, http://thehagueprocess.org/wordpress/wp-content/uploads/2015/03/3-THP-StateoftheArtReview-optimised-2010.pdf (dostęp 18.03.2018).

UNCTAD, 2017, The Least Developed Countries Report 2017, https://unctad.org/en/PublicationsLibrary/ldcr2017_en.pdf.

Upadhyay D.K., Migrant Crisis in Europe: Causes, Responses and Complexities, http://www.icwa.in/ pdfs/guestcolumn/2014/MigrantCrisisinEurope26042016.pdf (dostęp 18.03.2018).

Vathis O., 2013, Aid effectiveness: a literature review, Jean Monnet Papers on Political Economy $01 / 2013$.

Węgliński J., 2012, Imigracja a globalizacja. Przykład Stanów Zjednoczonych. Wydawnictwo Naukowe Scholar, Warszawa.

Zientara P., 2012, Międzynarodowe migracje o charakterze ekonomicznym: przyczyny, mechanizmy, konsekwencje, Wydawnictwo Uniwersytetu Gdańskiego, Gdańsk.

Zimmermann K.F. (red.), 1992, Migration and Economic Development, Springer-Verlag, Berlin. 